\title{
Supporting Self-Directed Learning by Connectivism and Personal Learning Environments
}

\author{
P. W. Conradie
}

\begin{abstract}
The traditional learning approaches (i.e. educational philosophies or paradigms) of behaviouralism, humanism, cognitivism, social learning theory and constructivism, have been the foundation of instructional design and teaching practice. Connectivism, considered a learning paradigm in its infancy by some and a learning theory by others, augurs a more intrinsic approach for learning in the 21 century. This study explores the perceptions of 76 higher education learners regarding the use of a connectivism pedagogical approach through the use of personal learning environments. Forming part of a project to evaluate the effectiveness of personal learning environments to support self-directed learning, and thus indirectly self-regulated learning, semi-structured interviews was utilized. Results obtained include improve learner motivation, engagement, collaboration and self-actualization. Of special interest was the element of self-actualization, generally associated with humanism. In addition, learners found the new learning environment challenging, requiring them to think critical about module content. Self-directed learning, supported by the pedagogical approach of connectivism and personal learning environments, is postulated to be a crucial skill set for the $\mathbf{2 1}$ century learner.
\end{abstract}

Index Terms-Connectivism, self-directed learning, self-regulated learning, pedagogy.

\section{INTRODUCTION}

Learning is a complex process which constitutes an important element of human development over the centuries. In the last 125 years, specifically related to the disciplines of psychology and education, the study of learning has resulted in diverse perceptions on learning [1]. The most prominent of these perspectives include behavior (observable change in behavior), cognitive (change in internal schemata), human (fulfillment of personal potential), social learning (learning in social situation by observation) and constructive (construction of knowledge from experience). Based on these perspectives, specific learning paradigms have developed, including behaviorism [2], cognitivism [3], humanism [4], social learning theory [5] and constructivism [6]. These paradigms have again led to the creation of a diverse number of learning theories. Naturally, these learning theories are postulated to play an important part in instructional design. However, when learning theories are applied by instructional designers, not one, but multiple theories of learning are generally employed [7]. This is grounded on the diverse needs of educationalist, centered on the unique and diverse

Manuscript received July 12, 2 013; revised October 16, 2013.

P. W. Conradie is with Department of Information and Communication Technology, Vaal University of Technology, South Africa (e-mail: pieterc@vut.ac.za). environments in which teaching occurs. Connectivism, defined by Mallon [8] as an amalgamation of constructivism and cognitivism, is a direct result of a new "open" learning environment, enabled by Web 2.0. With Web 2.0, information is not only accessed, but also created by learners, thus fundamentally changing the way learners interact, function, communication and learn. Online informal learning has become the new frontier of learning. No more can the classroom be considered the main focal point. This online "informal" learning environment, either created by the learner or for the learner utilizing Web 2.0 resources, can be defined as a personal learning environment or personal learning network [9].

The availability of online Web 2.0 materials and resources are postulated to enhance and reinforce learning [10]. One of the prominent advantages is it reflective quantities, which allow learners to easily reflect on their own progress [11]. Furthermore, the support for peer feedback and peer collaboration is greatly enhanced by the use of Web 2.0. These elements are postulated to contribute to learner engagement and self-regulation, thus learners are more actively involved in the learning process, again positively influencing motivation and subsequently, performance [12]. Social media, specifically related to online cloud base social platforms (e.g. Facebook, Google+) are especially relevant in the use of Web 2.0 in education. Researchers and lecturers have created online communities of practice, utilizing Web 2.0 to increase learner performance [13]. Doolan [14] confirm the importance of the social context of learning, describing it as a central tenet of learning. By including a social element in learning, active learning is encouraged, in effect supporting learner participation, dialogue and engagement, with one another, the educator, and learning resources. Learning is thus embedded in social activity, culture and context, with meaning constructed through dialogue.

For the purpose of this study, the use of Web 2.0 in teaching and learning will be referred to as electronic learning (e-learning). Mobile learning can again be conceptualized as mobile e-learning. Blended learning can be defined as a combination of e-learning, in either a formal or an informal learning context, and traditional face-to-face learning.

The question for many educationalists is whether the traditional learning paradigms of behaviorism, cognitivism, humanism, social learning and constructivism, support the new blended approach to teaching and related learning activities. Learning activities utilize directly influence the level to which a learner is supported. Kop [15] highlights four activities which can augment learning. These include 
aggregation (accessing and gathering of a wide variety of resources), relation (reflection and association to existing knowledge), creation (production of educational artifacts) and sharing (communicating of created educational artifacts with others). These activities are not advocated by all learning paradigms. To practically implement e-learning or m-learning in diverse and distributed environments, it is postulated that a new paradigm of learning must be considered [16]. Connectivism advocates a view similar to the activity theory of Vygotsky [17], which considers knowledge to reside within systems, accessed through the active participation of learners. However, in the connectivism view, learning is the process of creating connections and developing networks. This allows the development of the concept of "know-where" (where knowledge can be obtained), compared to the "know-how" and "know-what" foci, of traditional learning paradigms ([18]-[20]). Empirical evidence towards the effectiveness of this new approach is lacking [21]. Research on whether connectivism can be substantiated is thus required. This study's main aim is thus to explore the practical implication of implementing a connectivist learning approach to support self-directed learning and thus indirectly self-regulated learning, utilizing personal learning environments.

In the next section, a theoretical background to self-directed and self-regulated learning will be provided, followed in section three by a review of the research method employed. Section four outlines the results and in the final section, closing remarks are provided.

\section{BACKGROUND}

When implementing any e-learning innovation, an essential element to consider is the supporting pedagogy ([22], [23]). Although pedagogy initially referred to only child education, it is now commonly utilize in referring to teaching strategies and techniques that educators employ in their teaching praxis [24]. Andragogy is again utilized to refer to teaching strategies and techniques utilized for adult education [9]. Today, the two terms are utilized based on assumptions made regarding the learners (e.g. maturity level) and learning styles (e.g. autonomy). When considering andragogy, thus adult education, self-directed learning has been a focal area of research since the 1970's. Houle [25] defines adult education as "the process by which men and women (alone, in groups, or in institutional settings) seek to improve themselves or their society by increasing their skill, knowledge, or sensitiveness". However, Cyril Houle contribution to self-directed learning came earlier, with the publication The Inquiring Mind (1961/1993), which brought to the forefront the view that adults should assume responsibility for their own learning.

Malcolm Knowles, a doctoral student of Houle, can be credited with the first use of the terms andragogy and self-directed learning. Knowles [26] defined self-directed learning or self-direction as "a process in which individuals take the initiative, with or without the help of others, in diagnosing their learning needs, formulating learning goals, identifying human and material resources for learning, choosing and implementing appropriate learning strategies, and evaluating learning outcomes" (p.18). Subsequently, Rogers [27], at the beginning of the knowledge era, stated "we are, in my view, faced with an entirely new situation in education where the goal of education if we are to survive, is the facilitation of change and learning. The only man who is educated is the man who has learned how to learn, the man that has realized that no knowledge is secure, that only the process of seeking knowledge gives a basis for security". From this dynamic viewpoint, and the phenomenal growth of knowledge, a reawakening in self-directed learning and its benefits for learning, has taken place [28].

In praxis, self-directed learning implies a shift of responsibility for learning planning from the educator to the learner, with the learner controlling the learning process. Skiff and Beckendorf [29] defines self-directed learning as the process of identifying learning needs, planning learning goals, discovering learning resources, implement required learning tactics and strategies, and subsequently evaluate learning outcomes. Self-directed learning thus nullifies the idea of a passive learner, but instead focuses on mutual dialogue between learner and educator, with the learner actively involved in knowledge construction [30]. Self-directed learning is thus principally and instructional method, focused on the actions of planning, implementing and evaluating learning. Jossberger, BrandGruwel, Boshuizen and van de Wiel [31] distinguish between the concepts self-directed learning and self-regulated learning, placing self-directed learning in the adult learning domain and self-regulated learning in the educational psychology domain. Self-directed learning can thus be viewed at the macro level (i.e. planning of learning trajectory), while self-reflected learning is placed at the micro level (i.e. learning task level, self-controlled learning activities). Thus, with self-regulated learning, specific learning activities required to reach learning goals are managed by the learner, while with self-directed learning, the learner is also responsible for creating their own learning goals (outcomes). Important to note, self-directed learning automatically implies that self-regulated learning takes place, but the reverse is not true [32]. It is possible to have self-regulated learning without self-directed learning. Additionally, self-direct learning and self-regulated learning refer to both an instructional design or method and a personal characteristic [31]. Thus, an educator can implement self-directed learning as an instructional method and also develop a learner skill set (e.g. initiative, personal responsibility, autonomy) to enable self-directed learning.

Several studies have reported a positive correlation between self-directed learning (thus also self-regulated learning) and academic performance. Gabrielle, Guglielmino and Guglielmino [33] found that undergraduate students had a higher academic performance when self-directed online media supplemented normal face-to-face lectures. Reio [34] reported similar results, supporting the premise that the use of pedagogy that increase self-direction in learners, must be encouraged. Similarly, Ho, Kuo and Lin [35] and Yen and Liu [36] reported that the implementation of self-directed learning in an online environment support learner success. Ho, Kuo and Lin [35] postulated that better self-directed learning habits facilitate online learning. Additionally, Yen 
and Liu [36] indicated that online learning requires a high level of self-motivation and autonomy, indicative to self-regulated learning. Self-motivation is a critical element in online learning, with reason for doing and learner self-efficiency again critical sub-elements [37]. Stockdale and Brockett [38] found that the antecedents of self-directed learning include motivation, initiative and self-efficacy. Li, Wright, Rukavina and Pickering [39] again reported that autonomy, self-control, self-responsibility and time management as relevant. Cho, Demei and Laffey [40] explored self-regulated learning in higher education, utilizing an online learning environment. Results indicated that lecturer presences, peer presence, sense of connectedness, all contributed to the success of self-regulated learning. Turker and Zingel [41], however, highlighted the importance of instructional design to support self-directed learning. During instructional design, learner information management (learning style), identity management (self-efficacy) and relationship management (collaboration), three cognitive processes, needs to be considered. If successfully meditated, learner self-directed learning competencies will be improved.

In conclusion, it is important to note that the key to self-directed learning is that learners need to become critically aware of their own learning [42]. This will, however, not happen if the lecturer is the only source of information. Thus, the lecturer's role must change from educator (explaining, demonstrating and correcting) to that of facilitator of learning, guiding active learning processes and activities [43]. True optimal performance of learners will only happen if external support (i.e. scaffolding) and self-directed practices are evident [44]. In the next section, the research method followed in the study will be considered.

\section{RESEARCH METHOD}

\section{A. Research Context}

The pedagogical aim of this research was to introduce learners to the three phases of self-regulated learning proposed by Zimmerman [44], namely forethought, performance and reflection. In the forethought phase, analyzing of learning task, goal setting, selecting of tactics and strategies, motivation and self-efficacy, are important elements that needs to be considered. In the performance phase, a learner needs to develop self-control, thereby implement their strategies, do time management and seek help if required. Learners also need to self-observe, thus self-monitor their progress. Finally, in the reflection phase, the learner self-judge, thus self-evaluate the work performed, measuring whether it was efficient and effective. By encouraging the development of personal learning environments, utilizing Web 2.0 resources, autonomy, self-control, self-responsibility and time management was encouraged. The most prominent Web 2.0 resources encourage for learners was Google Drive (i.e. rich internet application), PBWorks (i.e. blog/wiki) and Youtube (i.e. video sharing), which supported the creation of a creative, supportive and autonomous learning environment. Knowledge thus not only resided in the mind of the learner, as postulated by connectivism, but resided in a distributed form in a node, allowing continuous evaluation and adaption as new insights were obtained. Although connectivism is not bounded to an online Web 2.0 environment, it would be very difficult, if not impractical to implement a connectivist approach without it.

Utilizing semi-structured interviews, learners' perceptions regarding the use of a connectivity pedagogical approach was measure, implementing principles of self-regulated learning. Thus learners could decide which learning activities would support their learning the best, based on their maturity level and learning style. In so doing, active learning (requiring active participation of students in and outside the classroom), collaborative learning (requiring students to work in groups (circles) and in a group (community)), blended learning (utilizing face-to-face and online instruction) and individualism (each learner had his or her own personal learning environment), were encouraged. A main focal point was the creation of a challenging learning environment, in as well as outside the classroom.

\section{B. Participants}

In total, 76 learners participated in the study, all members of a fourth year Information and Communication Technology (ICT) class. This necessitated the application of convenient sampling, defined as a non-random sampling technique by Creswell [45].

\section{Data Collection}

Implemented as a single case study, semi-structured interviews $(n=76)$ were performed utilizing an interview guide with both open- and closed-ended questions. Interviews, compared to surveys, are generally more suited to explore social phenomenon, allowing for a more in-depth enquiry. Respondents were briefed that participation was voluntary, the importance of answering truthfully and assured that their responses would be anonymous and confidential. However, based on the context that the researcher was the lecturer for the module, this could have prejudice responses obtained. Utilizing a five-point Likert scale for close ended questions, the interview guide provided a framework to evaluate specific factors, including motivation, engagement, collaboration and self-actualization, highlighted in Table I.

\begin{tabular}{|c|c|c|}
\hline Factor & Description & Study \\
\hline Motivation & $\begin{array}{l}\text { Does the use of connectivism, } \\
\text { supported by self-regulated } \\
\text { learning, lead to higher } \\
\text { motivated learners? }\end{array}$ & [46] \\
\hline Engagement & $\begin{array}{l}\text { Do learners engage with the } \\
\text { information set more readily? }\end{array}$ & [47] \\
\hline Collaboration & $\begin{array}{l}\text { Do learners find collaboration } \\
\text { with other learners more } \\
\text { facilitated? }\end{array}$ & {$[28]$} \\
\hline $\begin{array}{l}\text { Self-Actualizat } \\
\text { ion }\end{array}$ & $\begin{array}{l}\text { Do learners feel more } \\
\text { emboldened regarding their } \\
\text { learning? }\end{array}$ & [48] \\
\hline
\end{tabular}

\section{Data Analysis}

Data analysis was performed by means of descriptive statistics (e.g. mean, standard deviation) for closed-ended questions and thematic analysis for open-ended questions. 
Validation and reliability of data for closed-ended questions were based on Cronbach's alpha and the comparison of standard deviation with average mean. Open-ended questions were analyzed by employing the strategy proposed by Braun and Clarke [49]. Initial codes were identified as features of the data by hand, after which subthemes and themes were identified. Data extracts that best exemplified the main theme(s) were subsequently ascertained.

TABLE II: STRATEGICAL APPROACHES TO ENSURE TRUSTWORTINESS

\begin{tabular}{|c|c|}
\hline Approaches & Strategies followed \\
\hline Credibility & Triangulation, Member checking \\
\hline Transferability & Detail descriptions \\
\hline Dependability & Audit trail, Reflexivity \\
\hline Confirmability & Audit trail, Reflexivity \\
\hline Authenticity & Verbatim quotes \\
\hline
\end{tabular}

To ensure trustworthiness, the strategies suggested by Lincoln and Guba [31] were adopted, listed in Table II.

\section{RESUlTS}

In total, $47(62 \%)$ males and $29(38 \%)$ females participated. Observed ages ranged from 21 to 29 , with the mean age being 23. In Table III, the factors measured by means of close-ended questions are depicted, with their means and standard deviation.

TABLE III: FACTOR MEAN AND STANDARD DEVIATION

\begin{tabular}{|c|c|c|}
\hline Factor & $M(n=76)$ & $S D$ \\
\hline Motivation & 3.61 & 0.92 \\
\hline Engagement & 4.27 & 0.77 \\
\hline Collaboration & 4.06 & 0.84 \\
\hline Self-Actualization & 3.89 & 0.69 \\
\hline Average & $\mathbf{3 . 9 5}$ & \\
\hline
\end{tabular}

The factors engagement and collaboration rated the highest, confirming the active and cooperative components required by connectivism and self-regulated learning. Although self-actualization also rated relatively high, motivation rated lowest, indicating the possible need for additional scaffolding for learners in the use of personal learning environments and self-regulated learning. Variability was low with the overall SD equal to 0.8 , which are less than a $1 / 4$ of the average mean. This serves to affirm that the measures were homogeneous. Internal consistency was confirmed by the calculation of Cronbach's alpha for each factor, depicted in Table IV.

TABLE IV: CRONBACH'S ALPHA VALUES

\begin{tabular}{|c|c|}
\hline Factor & Cronbach's Alpha \\
\hline Motivation & 0.73 \\
\hline Engagement & 0.81 \\
\hline Collaboration & 0.75 \\
\hline Self-Actualization & 0.79 \\
\hline
\end{tabular}

All values calculated were above 0.7 , confirming internal consistency [50]. Based on thematic analysis performed for open-ended question, one main theme was identified. Learners found the new pedagogical approach challenging, requiring critical thinking from them on the course curriculum and information set. This theme was narrated as:

- "I don't always understand how to access the resources on Google+ (learner 6)."

- "This way of learning is to [sic] hard. I want the lecturer to create the course material (learner 37)."

- "I don't like creating contributions, I don't know if I [sic] doing the right things (learner 41)."

Creating a challenging environment for learners is, based on research [7], contribute to effective instruction. However, initial confidence levels of learners are indicated to be low, as reported by Kop [15]. It is envisage that if more scaffolding is provided to support learners, thereby enabling them to more effectively plan and monitor their own learning activities, more positive results will be observed.

\section{CONCLUSION}

It is irrefutable that education is entering a period of "radical discontinuity" [51]. Web 2.0 will continue to be a major element in enabling learner autonomy, thereby support self-directed learning. Learners are and will expecting educational institutions to support collaboration and communication through the creation of challenging and relevant educational content. Connectivism, as a pedagogical approach, can serve as a valuable teaching framework for the development of communities of practice and personal learning environments. However, more learner autonomy will require learners to obtain the necessary skills to self-regulate their learning. The role of the educator as regulator of learning will thus diminish, with less emphasis on face-to-face instruction, and more focus on online and blended learning. Exposure of educators to connectivism and the importance of self-regulated learning will be needed. If not, learner's familiar with the opportunities provided by online learning will seek experts elsewhere, for example with online universities like Coursera and EdX. Educators must thus actively participate in research on emerging learning approaches and instructional methods, thereby influencing future developments and debates, hopefully to the advantages of their institution and learners. Furthermore, whatever online Web 2.0 tools are employed, it is important that they are appropriate for educational purposes [52]. This implies that it must be easy-to-use, support teaching and learning activities, be accessible and readily available.

Results of this research indicated that participants were motivated and engaged, with collaboration and self-actualizations supported. Some learners, however, found the personal learning environment construct and instructional method of self-regulation challenging, conceivably requiring more training and support from educators in the initial phase of use. Limitations of the study correlate to the relative small sample size and that only one implementation of a personal learning environment in a specific ICT module was explored. 
As a pedagogical approach, connectivism has merit and can create a challenging learning environment. As a learning theory, it draws on well-establish learning theories including constructivism and cognitivism. Connectivism, personal learning environments and self-directed learning will in the foreseeable future be important focal areas of research in eand m-learning, specifically when the entrance of massive open online courses in the educational domain are considered.

\section{REFERENCES}

[1] F. Ashworth, G. Brennan, K. Egan, R. Hamilton, and O. Saenz. (2004). Learning Theories in Higher Education. [Online]. Available: http://arrow.dit.ie/cgi/viewcontent.cgi?article=1003\&context=engsche leart.

[2] B. Skinner, Science and human behaviour, New York: Macmillan, 1953.

[3] R. Gagne, "Learning outcomes and their effects: Useful categories of human performance," American Psychologist, vol. 39, pp. 377-385, 1984.

[4] W. Huitt. (2009). Humanism and open education. Educational Psychology Interactive, Valdosta: Valdosta State University. [Online]. Available:

http://www.edpsycinteractive.org/topics/affect/humed.html.

[5] A. Bandura, Social learning theory, Englewood Cliffs: Prentice Hall, 1977.

[6] T. Boyle, "Designing for usability and effectiveness in a resource rich learning system," East-West Journal of Computers in Education, vol. 1 pp. 37-45, 1994.

[7] J. Gardner, "How award-winning professors in higher education use Merrill's first principles of instruction," International Journal of Instructional Technology and Distance Learning, vol. 8, pp. 3-16, 2011)

[8] M. Mallon, "Extending the learning process: Using the theory of connectivism to inspire student collaboration," CULS proceedings, vol. 3, pp. 18-27, 2013.

[9] M. Knowles, Androgogy in Action: Applying Modern Principles of Adult Learning, San Francisco: Jossey-Bass, 1984.

[10] H. Coates et al., "A critical examination of the effects of learning management systems on university teaching and learning," Tertiary Education \& Management, vol. 11, pp. 19-36, 2005.

[11] N. Selwyn, "Faceworking: exploring students' education-related use of Facebook. Learning," Media and Technology, vol. 34, pp. 157-174, 2009.

[12] E. Okoro et al., "Social Media and Networking Technologies: An Analysis of Collaborative Work and Team Communication," Contemporary Issues in Education Research (CIER), vol. 5, pp. 295-300, 2012.

[13] V. Benson and S. Morgan, "Social higher education: how effective is it?" presented at 8th International Conference on e-Learning, Cape Town, 2013.

[14] M. Doolan, "A Pedagogical Framework for Collaborative Learning in a Social Blended E-Learning Context," Cutting-edge Technologies in Higher Education, vol. 6, pp. 261-285, 2013.

[15] R. Kop, "The challenges to connectivist learning on open online networks: Learning experiences during a massive open online course," International Review of Research in Open and Distance Learning, vol. 12, pp. 19-38, 2011.

[16] G. Siemens. (2005). Connectivism: A learning theory for the digital age. International Journal of Instructional Technology and Distance Learning. [Online]. $2 . \quad$ Available: http://www.itdl.org/Journal/Jan_05/article01.htm.

[17] L. Vygotsky, Mind in society, Cambridge: Harvard University Press, 1978.

[18] S. Downes. (2005). An introduction to connective knowledge. Stephen's Web. [Online]. Available: http://www.downes.ca/cgi-bin/page.cgi?post=33034.

[19] S. Downes. (2006). Learning networks and connective knowledge. Instructional Technology Forum: paper 92. [Online]. Available: http://it.coe.uga.edu/itforum/paper92/paper92.html.

[20] E. Mechlova and M. Malcik, "ICT in Changes of Learning Theories," in Proc. 10th International Conference on Emerging eLearning Technologies and Applications, 2012, pp. 253-262.
[21] S. Downes. (2007). Re: "What connectivism is." Connectivism conference: University of Manitoba. [Online]. Available: http://tc.umanitoba.ca/moodle/mod/forum/discuss.php?d=12.

[22] P. Chou and W. Chen. (2008). Exploratory study of the relationship between self-directed learning and academic performance in a web-based learning environment. Online Journal of Distance Learning Administration. [online], Available: http://www.westga.edu/ distance/ojdla/spring111/chou111.html.

[23] T. Govindasamy, "Successful implementation of e-learning pedagogical considerations," Internet and higher education, vol. 4, pp. 287-299, 2002.

[24] Q. Wang, "A generic model for guiding the integration of ICT into teaching and learning," Innovations in education and teaching international, vol. 45, pp. 411-419, 2008.

[25] C. Houle, The inquiring mind, 3rd ed., Norman: Oklahoma Research Center for Continuing Professional and Higher Education, 1993.

[26] M. Knowles, Self-directed learning: A guide for learners and teachers, New York: Association Press, pp. 32, 1975

[27] C. Rogers, Freedom to Learn for the Eighties, Ohio: Merril, 1983.

[28] M. Dimitrova, M. Mimirinis, and A. Murphy, "Evaluating the flexibility of a pedagogical framework for e-Learning," in Proc. of the IEEE international conference on advanced learning technologies, 2004, pp. 291-295

[29] D. Skiff and P. Beckendorf, "Self-directed learning: a key ingredient for comprehensive training curriculum," Pipeline and gas journal, vol. 236, pp. 76-77, 2009.

[30] M. Fischer and M. Sugimoto, "Supporting self-directed learners and learning communities with sociotechnical environments," Research and practice in technology enhanced learning, vol. 1, pp. 31-64, 2006.

[31] H. Jossberger, S. Brandgruwel, H. Boshuizen, and M. Van De Wiel, "The challenge of self-directed and self-regulated learning in vocational education: a theoretical analysis and synthesis of requirements," Journal of Vocational Education \& Training, vol. 62 , pp. 415-440, 2010

[32] S. Loyens, J. Magda, and M. Rikers, "Self-directed learning in problem-based learning and its relationship with self-regulated learning," Educational Psychology Review, vol. 20, pp. 411-427, 2008

[33] D. Gabrielle, L. Guglielmino, and P. Guglielmino, "Developing self-directed learning readiness of future leaders in a military college though instructional innovation," International Journal of Self-Directed Learning, vol. 3, pp. 24-35, 2006.

[34] T. Reio, "Prior knowledge, self-directed learning readiness, and curiosity: Antecedents to classroom learning performance," International Journal of Self-Directed Learning, vol. 1, pp. 18-26, 2004.

[35] L. Ho, T. Kuo, and B. Lin, "Influence of online learning skills in cyberspace," Internet Research, vol. 20, pp. 55-71, 2009.

[36] C. Yen and S. Liu, "Learner autonomy as a predictor of course success and final grades in community college online courses," Journal of Educational Computing Research, vol. 41, pp. 347-367, 2009.

[37] E. Yukselturk and S. Bulut, "Predictors for student success in an online course," Educational Technology \& Society, vol. 10, pp. 71-83, 2007.

[38] S. Stockdale and R. Brockett, "Development of the PRO-SDLS: A measure of self-direction in learning based on the Personal Responsibility Orientation Model," Adult Education Quarterly, vol. 61, pp. 161-180, 2011

[39] Y. Lincoln and E. Guba, Naturalistic inquiry, London: SAGE Publications, 2000.

[40] M. Cho, S. Demei, and J. Laffey, "Relationships between self-regulation and social experiences in asynchronous online learning environments," Journal of Interactive Learning Research, vol. 21, pp. 297-316, 2010.

[41] M. Turker and S. Zingel. (2008). Formative interfaces for scaffolding self-regulated learning in PLEs. eLearning Papers. [Online]. Available: http://www.elearningeuropa.info/files/media/media15975.pdf.

[42] S. Merriam, R. Caffarella, and L. Baumgartner, Learning in adulthood: a comprehensive guide, 3rd ed., San Francisco: John Wiley, 2007.

[43] M. Zion and M. Slezak, "It takes two to tango: In dynamic inquiry, the self-directed student acts in association with the facilitating teacher," Teaching and teacher education, vol. 21, pp. 875-894, 2005.

[44] B. Zimmerman, "Development and adaptation of expertise: The role of self-regulatory processes and beliefs," in K. A. Ericsson, N. Charness, P. J. Feltovich, and R. R. Hoffman, ed., The Cambridge handbook of expertise and expert performance, pp. 683-703, New York: Cambridge University Press, 2006

[45] J. Creswell, Educational research: Planning, conducting, and evaluating quantitative and qualitative research, London: Prentice-Hall, 2004 
[46] D. Passey, C. Rogers, J. Machell, and G. McHugh. (2008). The motivational effect of ICT on pupils. [Online]. Available: http://www.dfes.gov.uk/research/data/uploadfiles/RR523new.pdf.

[47] A. Granic, C. Mifsud, and M. Cukusic, "Design, implementation and validation of a Europe-wide pedagogical framework for e-learning," Computers \& Education, vol. 53, pp. 1052-1081, 2009.

[48] M. Ocak, "Blend or not to blend: a study investigating faculty members perceptions of blended learning," World Journal on Educational Technology, vol. 2, pp. 196-205, 2010.

[49] V. Braun and V. Clarke, "Using thematic analysis in psychology," Qualitative Research in Psychology, vol. 3, pp. 77-101, 2006.

[50] D. Churchill and N. Churchill, "Educational affordances of PDAs: a study of a teacher's exploration of this technology," Computers \& Education, vol. 50, pp. 1439-1450, 2008.
[51] B. Kerr. (2007). A challenge to connectivism. Transcripts of Keynote Speech, Connectivism conference. [Online]. Available: http://ltc.umanitoba.ca/wiki/index.php?title=Kerr_Presentation.

[52] P. Conradie, "Applying system theory to develop mobile learning pedagogical framework," in Proc. the 8th International Conference on e-Learning, Cape Town, 2013, pp. 82-90.

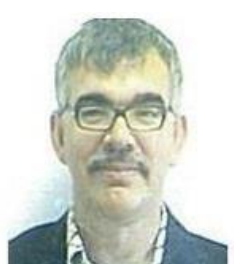

P. Conradie is a senior lecturer at the Vaal University of Technology, South Africa. He obtained his $\mathrm{PhD}$ (Computer Science) in 2010 from the North-West University, South Africa, an subsequently completed a PGCE in 2012. He is active research in the fields of e-learning, $\mathrm{m}$-learning and personal learning environments. 